\title{
The effect of pre- and post-pubertal feeding levels on the growth, reproduction, and future milk production of Simmental dairy heifers
}

\author{
J. Strzetelski ${ }^{1,3}$, J. Kowalczyk J. ${ }^{2}$ and K. Bilik ${ }^{1}$ \\ ${ }^{1}$ National Research Institute of Animal Production, Department of Animal Nutrition \\ 32-083 Balice, Poland \\ ${ }^{2}$ The Kielanowski Institute of Animal Physiology and Nutrition, Polish Academy of Sciences \\ 05-110 Jablonna, Poland
}

(Received 14 August 2006; revised version 20 March 2007; accepted 2 May 2007)

\begin{abstract}
The effect of pre- and post-puberty feeding of rations diversified in terms of energy and protein content on the growth rate, body condition, fatness, milk yield and reproduction efficiency of Simmental heifers was investigated. The experiment was carried out on 40 Simmental heifers from 6 months of age to day 100 of lactation, allotted to 5 groups according to age and body weight. During pre- (from 6 to 11 months of age) and post-puberty (from 12 to 13 months of age) the animals were fed rations of different or the same levels of energy (UFL) and protein (PDI) as the control Group K, which was fed according to IZ-INRA (2001). The respective levels of UFL and PDJ in the rations for the experimental groups in both periods were, $\%$ of control Group K : Group A, 85/85 and 115/115; Group B, 85/115 and 100/100; Group C, 115/85 and 100/100; Group D, 115/115 and 115/ 115. From 14 months of age to day 100 of lactation the animals of all groups were fed the same as the control group. Heifers that received higher UFL and lower BTJ (Group C) or increased levels of energy and protein (Group D) in their pre-puberty rations than the control group, at 11-18 months of age and in the period from 6 months of age to calving, achieved higher body weight gain than the animals of the remaining groups $(\mathrm{P}<0.05)$. Heifers fed rations with high pre-puberty energy levels (Groups C and D) and lower protein levels (Group C) calved about 40 days earlier and had a worse conception rate and insemination index $(\mathrm{P}>0.05)$ than animals in other groups. Total milk production per cow in Groups A and B was about 11\% higher than in Groups $\mathrm{K}$ and $\mathrm{D}$, and about $6 \%$ higher than in Group $\mathrm{C}$, but the differences were not statistically significant $(\mathrm{P}>0.05)$. Independently
\end{abstract}

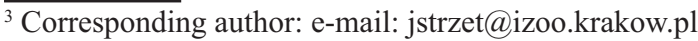


of the protein level, feeding Simmental heifers pre-puberty period ration with a low energy level followed by high-energy ration caused somewhat slower BWG from 6 months to calving, increased the age of first mating and calving but stimulated milk production in primiparous cows.

KEY WORDS: Simmental heifer, feeding level, condition, fatness, reproduction, milk yield

\section{INTRODUCTION}

The effect of energy and protein levels in rations on heifers during puberty depends on the genetic potential of animals (Sejrsen and Purup, 1997). The majority of reported results of experiments addressing this problem concern Holstein-Friesian heifers (Pirlo et al., 1997; Van Amburgh et al., 1998; Abeni et al., 2000; Silva et al., 2002). It was demonstrated that accelerating the growth of HF heifers during pre-puberty by providing higher concentrations of protein in the ration does not decrease their later milk production (Lammers and Heinrichs, 2000). Information is lacking, however, on the effect of energy and protein levels in rations for Simmental heifers during puberty on their later milk yield and reproduction traits.

The aim of the present study was to determine the effect of feeding Simmental heifers rations with diversified energy and protein levels, pre- and post-puberty, on their growth rate, body condition, fatness, milk and reproduction efficiency.

\section{MATERIAL AND METHODS}

\section{Animals, maintenance and feeding}

The experiment was carried out on 40 Simmental heifers of milk-meat type from 6 months of age to the end of 100 days of lactation. Animals were allotted to 5 groups taking into account age and body weight. During the pre-puberty period from 6 to 11 months of age and from 12 to 13 months of age the animals were fed rations with energy (UFL) and protein (PDI) levels differing or the same as the control Group K, which was fed according to IZ-INRA (2001) standards for a predicted body weight gain of $700 \mathrm{~g} \mathrm{day}^{-1}$ (Table 1). The UFL and PDJ levels in the ration for the experimental groups for both periods were, $\%$ of control Group K:

$\begin{array}{lll}\text { Group A }-85 / 85 & \text { and } & 115 / 115 \\ \text { Group B }-85 / 115 & \text { and } & 100 / 100 \\ \text { Group C }-115 / 85 & \text { and } & 100 / 100 \\ \text { Group D }-115 / 115 & \text { and } & 115 / 115\end{array}$


The compositions of rations and feeding design are given in Table 1.

From 14 months of age to 3 week before calving heifers and afterwards primiparous cows of all groups were fed until 100 days of lactation rations similar as animals of control Group K, assuming maximum milk production at the peak of lactation of 20 $\mathrm{kg} \mathrm{day}^{-1}$. The animals were kept tied in straw-bedded stalls and fed individually twice daily with free access to water. Roughage and concentrate were fed from separate feeders, feed intake and refusals were controlled daily. It was assumed that heifers are to be inseminated at the age of 16 months and body weight of $390 \mathrm{~kg}$.

Table 1. Experimental feeding design

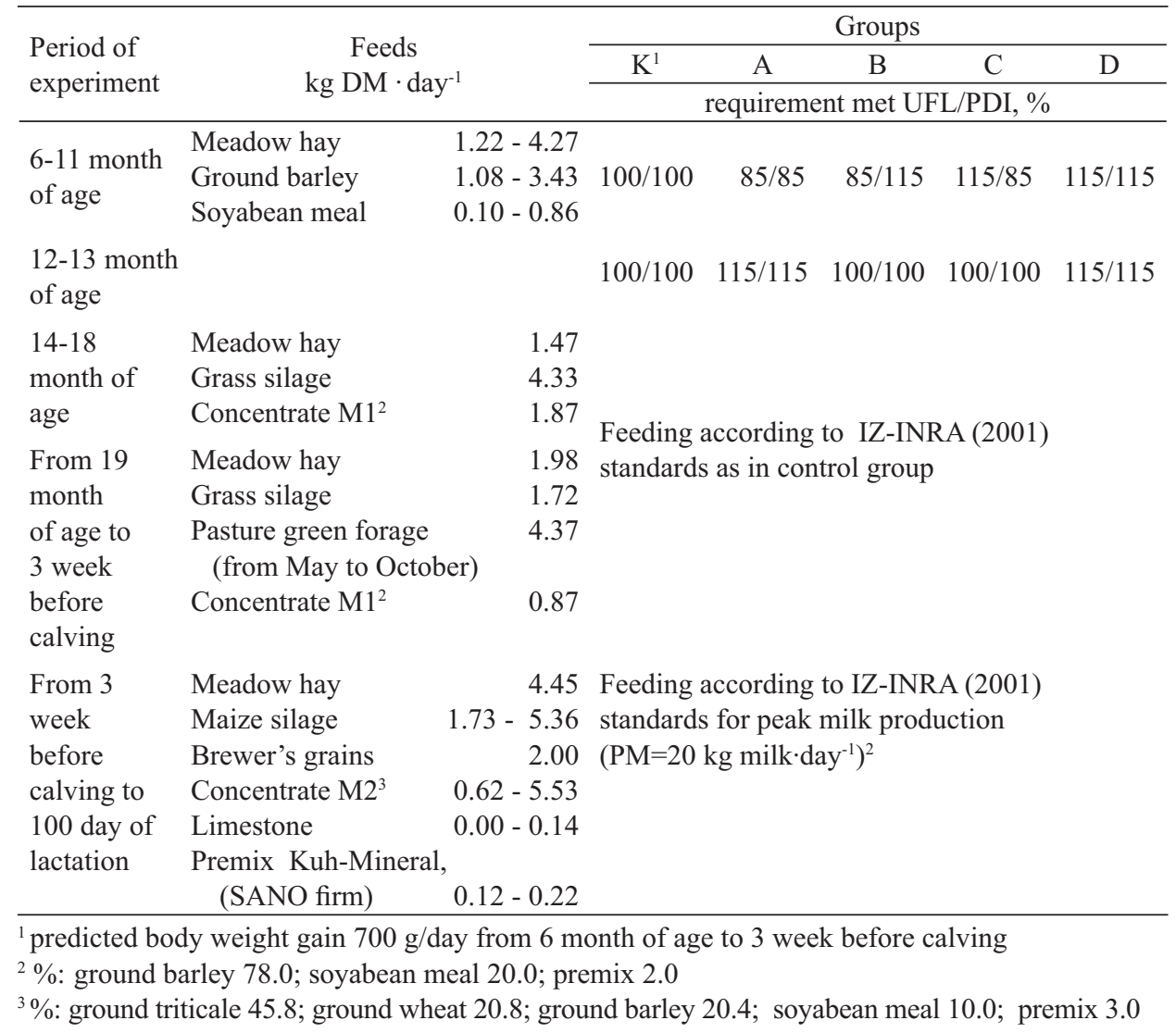

\section{Sampling, analysis and measurements}

Samples of meadow hay, grass and maize silage and concentrate were taken in one-month intervals and of green forage from pasture or refusals, in two-three week intervals. 
The proximate composition of feeds and refusals was estimated according to AOAC (1990). Silages were also analysed for volatile fatty acid (VFA) content using a Varian $3400 \mathrm{GC}$ with a $30 \mathrm{~m}$ FFAP column and $8200 \mathrm{CX}$ autosampler, and for lactic acid using a Shimadzu HPLC with a Nucleosil 250/4-C18 column and UV detector, the $\mathrm{pH}$ of silage was determined potentiometrically.

Milk samples were taken once a week after the morning milking and analysed for dry matter, fat, protein, casein, urea and lactose using a MILKO-SCAN FT Foss Electric apparatus.

Cows were milked twice a day and the milk yield of each cow was measured daily using TRU-TEST equipment.

Body weight and height at withers were measured and the body condition score (BCS) was estimated according to a 5-point scale according to Wildman et al. (1982). Width at the hip and ischiatic tubers and pelvis length were measured to calculate the index of pelvis area (PAI) according to Tyczka (1998). Subcutaneous backfat thickness (SFT) at the last pectoral vertebra was measured for each animal at age 6,11, 13 and 18 months and day 7 before and 35 after calving using an ALOKA SSD-500 Mikrus (CO., LTD, Japan) apparatus with linear head $3.5 \mathrm{MHZ}$ of $120 \mathrm{~mm}$ working wideness.

Reproductive traits were estimated on the basis of insemination and conception rate, age and body weight at first calving. Labour was assessed using a 3-grade scale: spontaneous (easy without intervention), moderate (easy pull), and difficult (veterinary intervention) (Pirlo et al., 1997).

\section{Calculations}

Feed energy and protein values, components of concentrate, and ration compositions were determined according to IZ-INRA (2001) standards using WINWAR (2000) and INRA'tion (1998/2001) software.

The results were subjected to one-way variance analysis using the GLM procedure and coefficients of correlation between estimates of BCS and SFT were calculated using the CORR procedure (SAS, 1999/2001). Statistica (1992) software was used for corrected lactation curves calculated on the basis of mean daily milk yield of each cow during subsequent weeks of lactation. The values in the tables marked with different letters differ significantly $(\mathrm{P}<0.05)$, no letters - the differences are not statistically significant $(\mathrm{P}>0.05)$.

\section{RESULTS}

The chemical composition of roughages and concentrate components, and their nutritive value are given in Table 2. Daily energy (UFL) and intestine digestible protein (PDI) intakes differed between groups of animals from \pm 13 to 
$\pm 15 \%$ in the pre- (6-11 months of age) and post-puberty (from 12-13 months of age) periods and were similar to values predicted according to the applied feeding levels of energy and protein (Table 3). Daily intake of nutrients in the remaining experimental period did not differ significantly $(\mathrm{P}>0.05)$.

Table 2. Chemical composition (\% of DM) and nutritive value of feeds, in $1 \mathrm{~kg} \mathrm{DM}$

\begin{tabular}{|c|c|c|c|c|c|c|c|c|c|}
\hline \multirow{2}{*}{ Item } & \multirow{2}{*}{$\begin{array}{c}\text { Meadow } \\
\text { hay }\end{array}$} & \multirow{2}{*}{$\begin{array}{l}\text { Grass } \\
\text { silage }\end{array}$} & \multirow{2}{*}{$\begin{array}{l}\text { Maize } \\
\text { silage }\end{array}$} & \multirow{2}{*}{$\begin{array}{l}\text { Green } \\
\text { forage }\end{array}$} & \multirow{2}{*}{$\begin{array}{l}\text { Brewer's } \\
\text { grains }\end{array}$} & \multirow{2}{*}{ Barley } & \multirow{2}{*}{$\begin{array}{c}\text { Soyabean } \\
\text { meal }\end{array}$} & \multicolumn{2}{|c|}{ Concentrate } \\
\hline & & & & & & & & M1 & M2 \\
\hline $\mathrm{DM}$ & 87.06 & 36.63 & 23.00 & 17.50 & 24.90 & 86.82 & 88.26 & 87.21 & 87.00 \\
\hline Ash & 7.04 & 5.31 & 5.21 & 10.68 & 4.45 & 2.91 & 7.35 & 3.26 & 6.09 \\
\hline Crude protein & 10.29 & 12.98 & 7.21 & 15.88 & 25.50 & 11.92 & 50.09 & 19.33 & 18.96 \\
\hline Crude fat & 2.28 & 3.04 & 2.30 & 2.17 & 8.59 & 1.69 & 1.60 & 1.93 & 2.87 \\
\hline Crude fibre & 31.70 & 31.39 & 23.0 & 27.83 & 20.36 & 6.15 & 7.11 & 6.15 & 7.24 \\
\hline $\mathrm{ADF}$ & 34.72 & 36.30 & 42.17 & - & - & - & - & - & - \\
\hline $\mathrm{NDF}$ & 56.97 & 54.47 & 65.13 & - & - & - & - & - & - \\
\hline $\mathrm{pH}$ & - & 4.18 & 3.75 & - & - & - & - & - & - \\
\hline \multicolumn{10}{|l|}{ In $1 \mathrm{~kg}$ of DM } \\
\hline $\mathrm{FP}^{1}, \mathrm{~g}$ & - & 65 & 143 & - & - & - & - & - & - \\
\hline PDIN, g & 64.0 & 76.0 & 44.3 & 100.0 & 188.8 & 78.3 & 356.9 & 134.0 & 123.0 \\
\hline PDIE, $g$ & 70.0 & 67.1 & 62.2 & 90.9 & 172.7 & 101.4 & 247.0 & 130.7 & 124.0 \\
\hline UFL & 0.62 & 0.81 & 0.91 & 0.86 & 0.93 & 1.15 & 1.19 & 1.16 & 1.34 \\
\hline
\end{tabular}

${ }^{1}$ fermentation products (lactic acid + acetic acid + butyric acid)

Table 3. Daily nutrients intake

\begin{tabular}{|c|c|c|c|c|c|c|c|}
\hline \multirow{2}{*}{$\begin{array}{l}\text { Period of } \\
\text { experiment }\end{array}$} & \multirow{2}{*}{ Item } & \multicolumn{5}{|c|}{ Groups } & \multirow{2}{*}{ RMSE } \\
\hline & & $\mathrm{K}$ & A & $\mathrm{B}$ & $\mathrm{C}$ & $\mathrm{D}$ & \\
\hline \multirow{4}{*}{$\begin{array}{l}\text { 6-11 month } \\
\text { of age }\end{array}$} & $\mathrm{DM}, \mathrm{kg}$ & $5.07^{\mathrm{a}}$ & $4.43^{\mathrm{b}}$ & $4.45^{\mathrm{b}}$ & $4.15^{b}$ & $5.27^{\mathrm{a}}$ & 0.25 \\
\hline & PDIN, g & $389.0^{\mathrm{a}}$ & $334.6^{\mathrm{b}}$ & $444.3^{c}$ & $334.5^{\mathrm{b}}$ & $447.5^{c}$ & 18.3 \\
\hline & PDIE, g & $416.1^{\mathrm{a}}$ & $357.8^{\mathrm{b}}$ & $474.3^{c}$ & $351.5^{\mathrm{b}}$ & $481.3^{c}$ & 20.9 \\
\hline & UFL & $3.87^{\mathrm{a}}$ & $3.37^{\mathrm{b}}$ & $3.35^{\mathrm{b}}$ & $4.42^{c}$ & $4.39^{\mathrm{c}}$ & 0.21 \\
\hline \multirow{4}{*}{$\begin{array}{c}12-13 \text { month } \\
\text { of age }\end{array}$} & $\mathrm{DM}, \mathrm{kg}$ & 6.05 & 6.28 & 6.08 & 6.15 & 6.15 & 0.29 \\
\hline & PDIN, $g$ & $453.8^{\mathrm{a}}$ & $519.6^{\mathrm{b}}$ & $462.5^{\mathrm{a}}$ & $463.0^{\mathrm{a}}$ & $521.0^{\mathrm{b}}$ & 25.1 \\
\hline & PDIE. g & $498.1^{\mathrm{a}}$ & $565.8^{\mathrm{b}}$ & $498.3^{\mathrm{a}}$ & $508.7^{\mathrm{a}}$ & $567.8^{\mathrm{b}}$ & 23.9 \\
\hline & UFL & $4.74^{\mathrm{a}}$ & $5.38^{\mathrm{b}}$ & $4.67^{\mathrm{a}}$ & $4.85^{\mathrm{a}}$ & $5.40^{\mathrm{b}}$ & 0.21 \\
\hline \multirow{4}{*}{$\begin{array}{l}\text { From } 14 \\
\text { month of } \\
\text { age to } \\
\text { calving }\end{array}$} & $\mathrm{DM}, \mathrm{kg}$ & 6.81 & 7.08 & 7.11 & 7.10 & 7.12 & 0.28 \\
\hline & PDIN, g & 577.4 & 594.8 & 591.4 & 590.2 & 594.3 & 16.0 \\
\hline & PDIE, g & 594.6 & 609.1 & 609.2 & 605.9 & 611.4 & 18.9 \\
\hline & UFL & 6.00 & 6.09 & 6.10 & 6.11 & 6.12 & 0.26 \\
\hline From $1^{\text {th }}$ to & DM, kg & 14.52 & 14.65 & 14.58 & 14.61 & 14.62 & 0.98 \\
\hline $100^{\text {th }}$ day & PDIN, $g$ & 1372.0 & 1385.6 & 1378.3 & 1384.0 & 1381.8 & 93.5 \\
\hline of & PDIE, g & 1416.1 & 1430.5 & 1424.0 & 1425.2 & 1426.4 & 97.9 \\
\hline lactation & UFL & 13.66 & 13.81 & 13.75 & 13.90 & 13.77 & 0.53 \\
\hline
\end{tabular}

a,b,c $-\mathrm{P}<0.05 ;{ }^{1} \sqrt{\mathrm{s}^{2}}$ 
Table 4. Liveweight and body size, daily weight gains, body condition score (BCS) and fatness (SFT)

\begin{tabular}{ccccccc}
\hline \multirow{2}{*}{ Item } & \multicolumn{7}{c}{ Groups } \\
\cline { 2 - 6 } & $\mathrm{K}$ & $\mathrm{A}$ & $\mathrm{B}$ & $\mathrm{C}$ & $\mathrm{D}$ & RMSE \\
\hline $\begin{array}{l}\text { Liveweight at month of } \\
\text { age, } \mathrm{kg}\end{array}$ & & & & & & \\
6 & $165.4^{\mathrm{a}}$ & 172.7 & 173.8 & 163.3 & 165.5 & 18.34 \\
11 & $267.6^{\mathrm{a}}$ & $248.1^{\mathrm{a}}$ & $250.0^{\mathrm{a}}$ & $292.0^{\mathrm{b}}$ & $301.0^{\mathrm{b}}$ & 19.20 \\
13 & $310.8^{\mathrm{a}}$ & $311.4^{\mathrm{a}}$ & $298.2^{\mathrm{a}}$ & $336.8^{\mathrm{b}}$ & $357.8^{\mathrm{b}}$ & 18.35 \\
18 & $421.1^{\mathrm{a}}$ & $420.8^{\mathrm{a}}$ & $406.5^{\mathrm{a}}$ & $444.2^{\mathrm{b}}$ & $456.3^{\mathrm{b}}$ & 20.26
\end{tabular}

Height at withers at month of age, $\mathrm{cm}$

$\begin{array}{lccllll}\quad & 102.6 & 102.7 & 103.5 & 102.2 & 103.6 & 3.31 \\ 11 & 112.9^{\mathrm{a}} & 112.2^{\mathrm{a}} & 113.1^{\mathrm{ab}} & 112.0^{\mathrm{a}} & 115.6^{\mathrm{b}} & 4.03 \\ 13 & 11.7 & 116.8 & 116.9 & 117.2 & 118.8 & 3.17 \\ 18 & 123.4^{\mathrm{a}} & 123.8^{\mathrm{a}} & 123.0^{\mathrm{a}} & 122.8^{\mathrm{a}} & 125.9^{\mathrm{b}} & 3.63 \\ \text { near by calving } & 131.4 & 132.5 & 132.5 & 133.5 & 134.4 & 3.57 \\ & & & & & & \\ & & & & & & \end{array}$

Liveweight gains from to month of age and for all experimental period $\mathrm{g} / \mathrm{day}$

$\begin{array}{lllllll}6-11 & 674.4^{\mathrm{a}} & 497.1^{\mathrm{b}} & 502.2^{\mathrm{b}} & 849.7^{\mathrm{c}} & 894.8^{\mathrm{c}} & 57.62 \\ 12-13 & 708.1^{\mathrm{a}} & 1044.6^{\mathrm{b}} & 795.2^{\mathrm{a}} & 722.5^{\mathrm{a}} & 931.2^{\mathrm{b}} & 62.90 \\ 6-18 & 697.8^{\mathrm{a}} & 679.4^{\mathrm{a}} & 637.0^{\mathrm{b}} & 769.0^{\mathrm{c}} & 797.0^{\mathrm{c}} & 29.63 \\ 6 \text { - }^{\text {calving }}{ }^{1} & 653.9^{\mathrm{a}} & 636.7^{\mathrm{a}} & 625.0^{\mathrm{a}} & 697.7^{\mathrm{c}} & 718.6^{\mathrm{c}} & 62.25\end{array}$

Body condition score at months of age, points

$\begin{array}{lllllll}6 & 2.95 & 2.93 & 2.95 & 2.99 & 3.01 & 0.16 \\ 11 & 3.28^{\mathrm{b}} & 3.08^{\mathrm{bc}} & 3.02^{\mathrm{bc}} & 3.86^{\mathrm{d}} & 3.98^{\mathrm{a}} & 0.23 \\ 13 & 3.45^{\mathrm{a}} & 3.37^{\mathrm{a}} & 3.45^{\mathrm{a}} & 3.80^{\mathrm{b}} & 3.90^{\mathrm{b}} & 0.21 \\ 18 & 3.65 & 3.55 & 3.57 & 3.64 & 3.65 & 0.22 \\ \text { near calving }^{1} & 3.80 & 3.84 & 3.86 & 3.76 & 3.81 & 0.22\end{array}$

Subcutaneous fat thickness at months of age, $\mathrm{mm}$

\begin{tabular}{lllllll}
6 & 2.96 & 2.96 & 2.94 & 3.01 & 3.01 & 0.18 \\
11 & $3.21^{\mathrm{a}}$ & $3.09^{\mathrm{a}}$ & $3.01^{\mathrm{a}}$ & $3.87^{\mathrm{b}}$ & $3.95^{\mathrm{b}}$ & 0.25 \\
13 & $3.38^{\mathrm{a}}$ & $3.39^{\mathrm{a}}$ & $3.45^{\mathrm{a}}$ & $3.76^{\mathrm{b}}$ & $3.92^{\mathrm{b}}$ & 0.23 \\
18 & 3.41 & 3.47 & 3.50 & 3.52 & 3.57 & 0.59 \\
near calving $^{1}$ & 8.67 & 8.56 & 8.59 & 8.45 & 8.61 & 0.69 \\
\hline
\end{tabular}

${ }^{1}$ measurement: 7 days before calving; average age of calving $27 \pm 1.5$ months; ${ }^{a, b, c}-\mathrm{P} \leq 0.05$ 
Heifers that received during the pre-puberty period rations containing higher UFL and lower BTJ levels (Group C) or increased energy and protein levels (Group D) than the control group, in the monthly intervals from 11-18 months of age achieved higher BW and daily body weight gains $(\mathrm{P}<0.05)$ and for the entire period of experiment (from 6 months of age to calving) than animals of the remaining groups. Differences in BW before calving were not statistically significant among groups (Table 4). The heifers of Group D reached the highest height at withers at 11 and 18 months of age and the highest BCS and SFT at 11 and 13 months of age $(\mathrm{P}<0.05)$. Differences between the groups of animals at 18 months of age and at 7 days before calving in BCS or SFT and index of the pelvis area estimated before calving were statistically nonsignificant $(\mathrm{P}>0.05)$.

The animals of Groups A and B grew more slowly from 6 to 11 months of age than the animals of the other groups, but from 12 to 13 months of age the heifers of Group A reached the greatest daily BWG. When compared with Group $\mathrm{D}$ the differences were not significant, however.

Primiparous BW, BSC, height in withers or SFT did not differ among groups (Table 5).

Table 5. Liveweight, body size, body condition score (BCS) and subcutaneous fat thickness (SFT) of primiparous cows

\begin{tabular}{|c|c|c|c|c|c|c|}
\hline \multirow{2}{*}{ Item } & \multicolumn{5}{|c|}{ Groups } & \multirow{2}{*}{ RMSE } \\
\hline & $\mathrm{K}$ & A & $\mathrm{B}$ & $\mathrm{C}$ & $\mathrm{D}$ & \\
\hline \multicolumn{7}{|l|}{ Liveweight at day after calving, $\mathrm{kg}$} \\
\hline 7 & 531.4 & 526.2 & 529.2 & 537.2 & 542.3 & 14.59 \\
\hline 35 & 525.1 & 536.4 & 530.7 & 528.6 & 540.9 & 25.55 \\
\hline 100 & 566.6 & 565.6 & 539.2 & 548.2 & 564.9 & 35.03 \\
\hline \multicolumn{7}{|l|}{ Liveweight loss, $\%$} \\
\hline $\begin{array}{c}\text { from } 7^{\text {th }} \text { day before calving } \\
\text { to } 7^{\text {th }} \text { day of lactation }\end{array}$ & 9.95 & 10.31 & 9.41 & 9.60 & 9.71 & 2.67 \\
\hline $\begin{array}{l}\text { from } 7^{\text {th }} \text { day before calving } \\
\text { to } 35 \text { day of lactation }\end{array}$ & 11.01 & 8.87 & 9.20 & 11.03 & 9.21 & 3.33 \\
\hline $\begin{array}{l}\text { Height at withersat } 100 \text { days after } \\
\text { calving, cm }\end{array}$ & 134.4 & 134.4 & 134.8 & 136.4 & 136.6 & 3.15 \\
\hline \multicolumn{7}{|l|}{ BCS at days after calving, points } \\
\hline 7 & 3.10 & 3.08 & 3.11 & 3.17 & 3.16 & 0.209 \\
\hline 35 & 3.15 & 3.20 & 3.17 & 3.22 & 3.23 & 0.124 \\
\hline 100 & 3.43 & 3.51 & 3.41 & 3.41 & 3.44 & 0.097 \\
\hline SFT at 35 day after calving, $\mathrm{mm}$ & 6.37 & 6.45 & 6.20 & 6.10 & 5.76 & 0.16 \\
\hline
\end{tabular}


Even at a lower protein level (Group C), heifers fed rations providing higher energy levels in the pre-puberty period (Groups $\mathrm{C}$ and $\mathrm{D}$ ) calved about 40 days earlier $(\mathrm{P}<0.05)$ than in Groups $\mathrm{K}, \mathrm{A}$ and $\mathrm{B}$ (Table 6). Body weight at calving, conception rate and insemination index did not differ significantly among the groups $(\mathrm{P}>0.05)$. The majority of heifers delivered calves with no difficulty or easy pull, veterinary intervention was needed only in single cases in Groups $\mathrm{K}$ and $\mathrm{C}$.

Table 6. Reproductive performance and milk yield of primiparous cows

\begin{tabular}{lcccccr}
\hline \multirow{2}{*}{ Item } & \multicolumn{5}{c}{ Groups } & \multirow{2}{*}{ RMSE } \\
\cline { 2 - 6 } & $\mathrm{K}$ & $\mathrm{A}$ & $\mathrm{B}$ & $\mathrm{C}$ & $\mathrm{D}$ & \\
\hline Conception rate, \% & 87.5 & 87.5 & 75.0 & 75.0 & 62.5 & 43.51 \\
Insemination index & 1.12 & 1.12 & 1.25 & 1.25 & 1.28 & 0.43 \\
Calving age, months & $27.5^{\mathrm{a}}$ & $27.5^{\mathrm{a}}$ & $27.6^{\mathrm{a}}$ & $26.4^{\mathrm{b}}$ & $26.0^{\mathrm{b}}$ & 0.90 \\
& & & & & & \\
Liveweight at calving, kg & 590.0 & 588.2 & 584.2 & 594.7 & 607.7 & 14.85
\end{tabular}

Calving difficulties, number of cows

$\begin{array}{lrrrrrr}\text { spontaneous calving } & 5 & 5 & 4 & 4 & 4 & - \\ \begin{array}{l}\text { calving with moderate pulling } \\ \text { calving with heavy pulling }\end{array} & 2 & 3 & 4 & 3 & 3 & - \\ & 1 & 0 & 0 & 1 & 0 & - \\ \text { Total milk yield, kg } & 1479.0 & 1628.6 & 1612.7 & 1511.6 & 1426.7 & 265.86 \\ & & & & & & \\ \text { Milk composition, \% } & 12.86 & 12.79 & 12.63 & 12.42 & 12.28 & 0.59 \\ \quad \text { dry matter } & 4.29 & 4.26 & 4.16 & 4.25 & 4.21 & 0.17 \\ \text { fat } & 3.37 & 3.34 & 3.27 & 3.33 & 3.43 & 0.20 \\ \text { protein } & 2.84 & 2.77 & 2.90 & 2.81 & 2.87 & 0.18 \\ \text { casein } & 4.84 & 4.91 & 4.90 & 4.88 & 4.88 & 0.08 \\ \text { lactose } & & & & & & \end{array}$

Yield of milk components, $\mathrm{kg}$

\begin{tabular}{lccccrr} 
fat & 63.3 & 69.5 & 67.5 & 64.7 & 59.9 & 12.05 \\
protein & 49.8 & 55.7 & 52.8 & 50.7 & 48.4 & 8.64 \\
lactose & 71.9 & 80.0 & 79.1 & 74.4 & 69.2 & 13.11 \\
& & & & & & \\
ilk urea concentration, mg/l & 178.9 & 161.8 & 204.2 & 192.2 & 178.6 & 47.70 \\
ak milk production (PM), kg/day & 18.22 & 19.32 & 19.00 & 18.77 & 18.0 & 0.18 \\
\hline
\end{tabular}

${ }^{1}$ similar as Pirlo et al. (1997)

The total milk yield of cows in Groups A and B was about 11\% higher than in primiparous cows in Groups $\mathrm{K}$ and D and about 6\% higher than in Group C, but the differences were not statistically significant $(\mathrm{P}>0.05)$. There was a tendency 
for animals in Groups A and B towards higher total milk production and yields of milk fat, protein, and lactose, and towards milk yield in peak lactation than in other groups. The urea content in milk did not differ among the groups (Table 6).

Changes occurring in the course of lactation also suggest a beneficial effect of the rations fed to animals of Groups A and B on milk production (Figure 1).

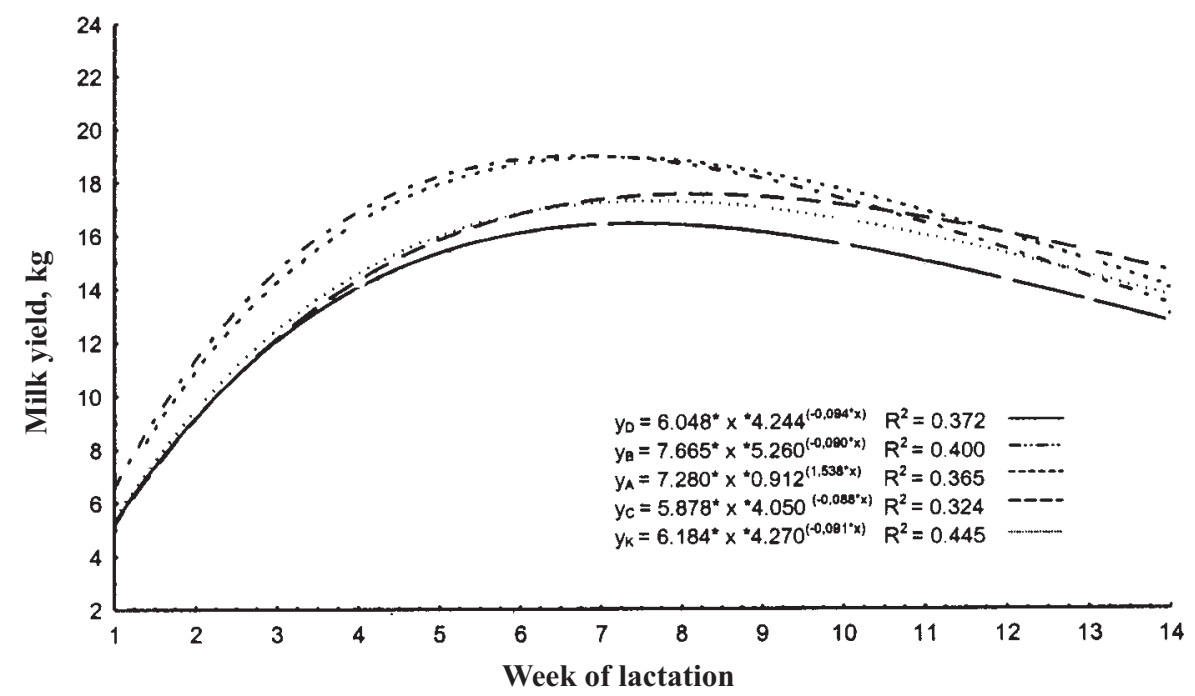

Figure 1. Changes of average daily milk yield in the following weeks of lactation; mean yields calculated from the formula: $\mathrm{y}=\mathrm{a}^{*} \mathrm{x}^{*} \mathrm{~b}^{\mathrm{c}^{*} \mathrm{x}} ; \mathrm{a}, \mathrm{b}, \mathrm{c}$ - coefficients, $\mathrm{x}$ - weeks of lactation

A highly significant dependence $(\mathrm{P}<0.01)$ between $\mathrm{BSC}$ and SFT at all ages of heifers, but especially at 6,11 and 13 months of age, was found (Table 7).

Table 7. Relationship between body condition score (BCS, pts) and subcutaneous backfat thickness (SFT, mm) in the heifers of different age, before calving and after calving

\begin{tabular}{lcccc}
\hline $\begin{array}{l}\text { Age (months) and } \\
\text { day after calving }\end{array}$ & $\begin{array}{c}\text { BCS } \\
(\mathrm{pts})\end{array}$ & Regression equations $(\mathrm{Y}=\mathrm{a}+\mathrm{b}$ x $)$ & $\begin{array}{c}\text { Correlation } \\
\text { coefficient } \\
\mathrm{R}\end{array}$ & $\begin{array}{c}\text { Level of } \\
\text { significance P }\end{array}$ \\
\hline 6 & 2.97 & $\mathrm{SFT}=-0.2175+1.076 * \mathrm{BCS}$ & 0.952 & $<0.01$ \\
11 & 3.45 & $\mathrm{SFT}=-0.0040+0.994 * \mathrm{BCS}$ & 0.975 & $<0.01$ \\
13 & 3.59 & $\mathrm{SFT}=-0.0255+1.006 * \mathrm{BCS}$ & 0.952 & $<0.01$ \\
18 & 3.61 & $\mathrm{SFT}=-1.1581+1.396 * \mathrm{BCS}$ & 0.430 & $<0.01$ \\
7 day before calving & 3.82 & $\mathrm{SFT}=-0.0673+2.129 * \mathrm{BCS}$ & 0.543 & $<0.01$ \\
35 day of lactation & 3.20 & $\mathrm{SFT}=-0.0673+2.129 * \mathrm{BCS}$ & 0.448 & $<0.01$ \\
\hline
\end{tabular}




\section{DISCUSSION}

Body weights in all groups of animals attained at the respective times of measurement were in line with the standards recommended for milk-meat type Simmental heifers and primiparous cows. Decreasing the energy and protein levels by $15 \%$ in the ration fed in the pre-puberty period (from 6 to 11 months of age) in Group A compared with Group K did not decrease the body weight at age 18 months or in the calving period. This could be explained by the phenomenon of growth compensation as the ration for these animals directly after reaching the end of puberty was increased by $30 \%$ in protein and energy. The highest daily body weight gain obtained in this group from 12 to 13 months of age suggests such an interpretation. However, increasing the protein level in the diet for group B by $30 \%$ in comparison with group A and at a similar energy level as in the Group A had no beneficial effect on daily body weight gain during puberty, suggesting that protein was utilized worse than energy in an energy-deficient ration. The higher body weight gains of animals in group $\mathrm{C}$ given the ration with an energy level increased by $30 \%$ and the same protein level as compared with Group B also supports this suggestion.

Indices describing body condition and fatness in the pre-puberty period show that Simmental heifers fed a diet enriched in energy but with a lower protein level (Group C) or fed a diet enriched in energy and protein (Group D) had higher condition and fatness scores at the age of 11 and 13 months than at those fed lower energy levels. A similar tendency of HF heifers fed during pre-puberty rations with $10-15 \%$ higher net energy and crude protein levels compared with ones fed according to NRC (1989) standards established for $700 \mathrm{~g} /$ day body gain was reported by Daccaret et al. (1993), Pirlo et al. (1997), Van Amburgh et al. (1998) and Abeni et al. (2000).

Despite differences in the level of energy and protein fed pre- and post-puberty resulting in increased body condition and fatness scores of heifers at the ages of 11 and 13 months, there were no significant differences in these indices in animals at 18 months of age or on the day before calving, as compared with the control group. This suggests that the levet of energy and protein in the rations for both periods does not result in excessive fatness of Simmental heifers at the reproduction and calving stages when in the subsequent period of rearing the heifers are fed as the control group according to IZ-INRA (2001) standards established for gains of 700 $\mathrm{g} /$ day. The tendency of BSC and SFT to increase with the age of heifers is also known in other breeds (Hoffman, 1997; Waldo et al., 1997; Arango et al., 2002; Bilik and Strzetelski, 2005).

The reproduction indices of heifers fed higher energy and protein (Group D) or higher energy and lower protein (Group C) levels from 6 to 11 months of age suggest the possibility of acceleration of reproduction by 6-7 weeks compared 
with heifers fed rations of lower energy value, independently of protein level (Peri et al., 1993; Vicini et al., 1995; Pirlo et al., 1997; Sejrsen and Purup, 1997).

Differentiated levels of energy and protein in the rations fed before and after puberty in our experiment did not negatively affect the course of parturition, supporting the results obtained for HF heifers by Choi et al. (1997) and Pirlo et al. (1997). Development and shape of heifer pelvises before calving measured as the value of the pelvic surface index (Tyczka, 1998) were characteristic of an easier course of parturition.

The superior production effects of primiparous cows in Group A and B than in other groups point to the greater usefulness of feeding Simmental heifers rations with lower energy levels in the pre-puberty period. This feeding method resulted in higher milk, fat, protein, and lactose production by heifers and better efficiency of nutrients per kg milk production. It can be supposed that the lower level of energy fed to milk type Simmental heifers as in Groups A and B than given in IZINRA (2001) standards results in better development of secretory tissue and lower fatness of the mammary gland in heifers (Stelwagen and Grive, 1990; Park et al., 1998; Strzetelski et al., 2004).

The $9 \%$ higher milk production in Group B, fed a 15\% higher PDI level and lower level of energy during pre-publerty, might also be caused by better development of mammary gland secretory tissue (Stelwagen and Grive, 1990; Capuco et al., 1995; Dobos et al., 2000; Silva et al., 2002). However, the differences in milk production reported by them as well as in our experiment were not statistically significant $(\mathrm{P}>0.05)$. The contents of fat, protein and casein in the milk produced by all groups of animals indicate a high value for milk and cheese production. The urea level in milk of all experimental animals points to a correctly balanced ration for cows (Nagel, 1994; Weniger and Distl, 1994).

Taking into consideration the high relationship between BCS and SFT in different stages of growth it is supposed that the precise estimation of body condition on a 5-point scale may be sufficient to determine the degree of fatness of Simmental heifers.

\section{CONCLUSIONS}

The results obtained during the Simmental heifer feeding trial indicate that during the pre-puberty period from 6 to 11 months of age, it is advisable to decrease the dietary energy level by about $15 \%$ in relation to IZ-INRA standards for an assumed BWG of $700 \mathrm{~g} /$ day. The feeding level of protein before puberty and the feeding levels of energy and protein after puberty have little significance. A decreased level of energy fed before puberty in relation to the control group improves the reproductive parameters of heifers and stimulates milk production 
in the first lactation. The approximately $15 \%$ higher level of energy and protein in rations for Simmental heifers before and after puberty, decreases the age of first mating and calving, but has a negative effect on milk productivity during the first lactation.

\section{REFERENCES}

Abeni F., Calmari L., Stefanini L., Pirlo G., 2000. Effects of daily gain in pre- and postpubertal replacement dairy heifers on body condition score, body size, metabolic profile, and future milk production. J. Dairy Sci. 83, 1468-1478

AOAC, 1990. Association of Official Analytical Chemists, Official Methods of Analysis. $15^{\text {th }}$ Editon. Arlington, VA

Arango J.A., Cundiff L.V., Vleck L.D., 2002. Breed comparison of Angus, Charolais, Hereford, Jersey, Limousin, Simmental and South Devon for weight, weight adjusted for body condition score, height, and body condition score of cows. J. Anim. Sci. 80, 3123-3132

Bilik K., Strzetelski J.A., 2005. Effect of a simplified "stair-step" feeding system on the performance of Red-and-White Holstein-Friesian heifers. J. Anim. Feed Sci. 14, Suppl. 1, 219-222

Capuco A.V., Smith J.J., Waldo D.R., Rexroad Jr. C.E., 1995. Influence of pre-pubertal dietary regimen on mammary growth of Holstein heifers. J. Dairy Sci. 78, 2709-2725

Choi Y.J., Han J.K., Woo J.H., Lee H.J., Jang K., Myung K.H., Kim Y.S., 1997. Compensatory growth in dairy heifers: the effect of a compensatory growth pattern on growth rate and lactation performance. J. Dairy Sci. 80, 519-524

Daccarett M.G., Bortone E.J., Isbell D.E., Morrill J.L., Feyerherm A.M., 1993. Performance of Holstein heifers fed $100 \%$ or more of National Research Council requirements. J. Dairy Sci. 76, 606-614

Dobos R.C., Nandra K.S., Riley K., Fulkerson W.J., Lean I.J., Kellaway R.C., 2000. The effect of dietary protein level during the pre-pubertal period of growth on mammary gland development and subsequent milk production in Friesian heifers. Livest. Prod. Sci. 63, 235-243

Hoffman P.C., 1997. Optimum body size of Holstein replacement heifers. J. Anim. Sci. 75, 836-845

INRA'tion, 1998/2001. Software for Calculation of Ration Composition for Ruminants ver. 2.63 (in Polish). DJ Group, Kraków (Poland)

IZ-INRA, 2001. Feeding Standards for Cattle, Sheep and Goats. Nutritient Value of Feeds for Ruminants as Elaborated According to INRA 1988 (in Polish). Research Institute of Animal Production (Editor), Kraków (Poland), pp. 313

Lammers B.P., Heinrichs A.J., 2000. The response of altering the ration of dietary protein to energy on growth, feed efficiency and mammary development in rapidly growing pre-pubertal heifers. J. Dairy Sci. 83, 977-983

Nagel S., 1994. Harnsstoffbericht: Neues Modell für große Herden. Tierzüchter 46 (9), 28-31

NRC, 1989. Nutrient Requirements of Dairy Cattle. $6^{\text {th }}$ revised Edition. National Research Council. Washington, DC

Park C.S., Danielson R.B., Kreft B.S., Kim S.H., Moon Y.S., Keller W.L., 1998. Nutritionally directed compensatory growth and effects on lactation potential of developing heifers. J. Dairy Sci. 81, 243-249

Peri J., Getler A., Bruchental J., Barash H., 1993. The effect of manipulation in energy allowance during the rearing period of heifers on hormone concentrations and milk production in first lactation cows. J. Dairy Sci. 39, 742-751 
Pirlo G., Capelleti M., Marchett G., 1997. Effect in energy and protein allowances on the diets of prepubertal heifers on growth and milk production. J. Dairy Sci. 80, 730-739

SAS, 1999/2001. Statistical Analyses System, Version 8.2. SAS User's Guide: Statistics SAS Institute, Inc., Carry, NC

Sejrsen K., Purup S., 1997. Influence of pre-pubertal feeding level on milk yield potential of dairy heifers. J. Anim. Sci. 75, 828-835

Silva L.F.P., VandeHaar M.J., Whitlock B.K., Radcliff R.P., Tucker H.A., 2002. Short communication: Relationship between body growth and mammary development in dairy heifers. J. Dairy Sci. $85,2600-2602$

Statistica, 1992. Statistical Analyses System, Version 5.1

Stelwagen K., Grive D.G., 1990. Effect of plane of nutrition on growth and mammary gland development in Holstein heifers. J. Dairy Sci. 73, 2333-2341

Strzetelski J., Bilik K., Niwińska B., Skrzyński G., Łuczyńska E., 2004. Ultrasound evaluation of the mammary gland tissue structure in pre-parturient heifers. J. Anim. Feed Sci. 13, Suppl. 2, 7-10

Tyczka J., 1998. Description and evaluation of some effects on the course of parturition of Red-andWhite cows (in Polish). Zesz. Nauk. AR Wrocław, Zoot. XLIV, 350, 173-197

Van Amburg M.E., Galton D.M., Bauman D.E., Everett R.W., Fox D.G., Chase L.E., Erb H.N., 1998. Effects of three pre-pubertal body growth rates on performance of Holstein heifers during first lactation. J. Dairy Sci. 81, 527-538

Vicini J.L., Olson P.K., Barnes B., Collier R.J., 1995. Effect of pre-pubertal accelerated growth, rate and somatotropin on subsequent milk production. J. Dairy Sci. 78, Suppl. 1, 180 (Abstr. P85)

Waldo D.R., Tyrrell H.F., Capuco A.V., Rexroad Jr. C.E., 1997. Components of growth in Holstein heifers fed either alfalfa or corn silage diets to produce two daily gains. J. Dairy Sci. 80, 16741684

Weniger A., Distl D., 1994. Harnstoff und Azetongehalt in der Milch als Indikatoren für Ernährungsbedingte Fruchtbarkeitssterungen der Milchkuh. Dt. Tierarztl. Wochenschr. 101, 152-157

Wildman E.E., Jones G.M., Wagner P.E., Boman R.J., Troutt H.F., Lesch T.N., 1982. A dairy cow body condition scoring system and its relationship to selected production characteristics. J. Dairy Sci. 65, 495-506

WINWAR, 2000. Software for Calculation Feed Value according IZ-INRA System ver. 1.63 (in Polish). DJ Group, Kraków (Poland) 